اثر حفاظتى نانوذرات اكسيدروى بر كبد و روند اختلالات القاءشده ازطريق داروى پاكلى تاكسل در

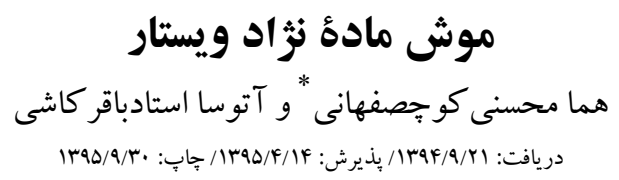

كروه علومجانورى، دانشكدة علومزيستى، دانشگاه خوارزمى، تهر ان، ايران

kouchesfehani@khu.ac.ir مسئول مكاتبات"

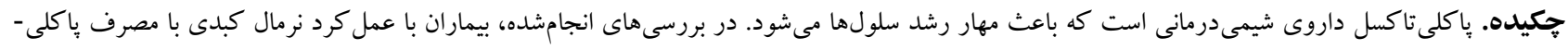

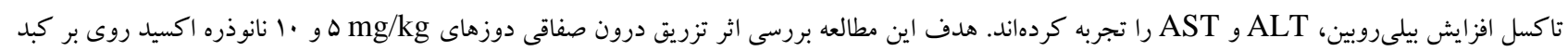

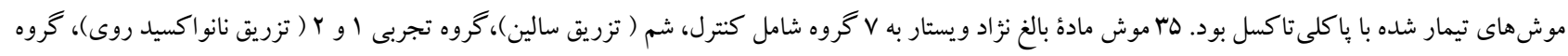

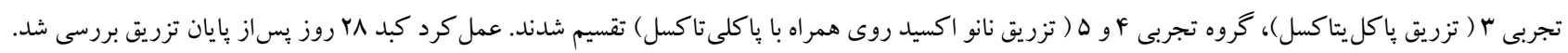

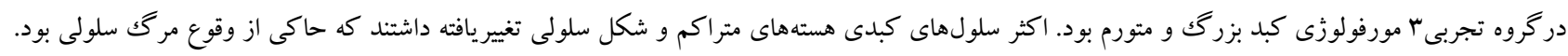

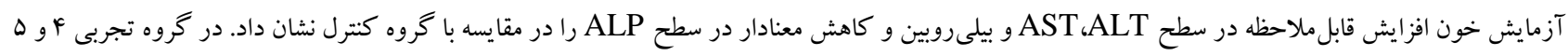

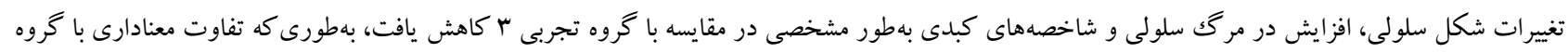

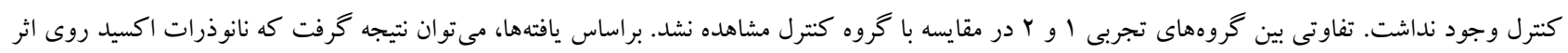

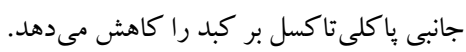
وازههاى كليدى. هيستوياتولوزى، شيمىدرمانى، ترانس آمينازها، بيلىروبين، آلكالين فسفاتاز

\title{
The protective effect of $\mathrm{ZnO}$ nanoparticles on liver and impairments induced by paclitaxel treatment in female Wistar rat
}

\section{Homa Mohseni Kouchesfahani ${ }^{*}$ \& Atousa Ostadbagher Kashi Received 12.12.2015/ Accepted 04.07.2016/ Published 20.12.2016}

Department of Animal Biology, Faculty of Biological Sciences, Kharazmi University, Tehran, Iran

*Correspondent author: kouchesfehani@khu.ac.ir

Abstract. Paclitaxel is a chemotherapy drug inhibiting cell growth. In some studies, patients with normal liver function have experienced increase in bilirubin, ALT and AST by using paclitaxel. The aim of this study was to evaluate the effect of intra-peritoneal injection of doses 5 and $10 \mathrm{mg} / \mathrm{kg} \mathrm{nZnO}$ on the liver of rats treated with paclitaxel. 35 adult female Wistar rats were divided into 7 groups including control, sham (saline injection), experimental groups 1 and 2 (nZnO injection), experimental group 3 (paclitaxel injection), experimental groups 4 and 5 (nZnO and paclitaxel injection). Liver function was examined 28 days after the end of injection. Experimental group3 had large and swollen liver morphology. Most hepatocytes had dense nuclei and changed cell shape indicating of cell death. Blood test showed significant increase in the levels of ALT, AST and bilirubin and decrease in the level of ALP in comparison with the control group. In experimental groups 4 and 5, cell shape alterations, increase in cell death and increase in liver markers were remarkably reduced in comparison with the experimental group 3, in a way that there were no significant differences with the control group. No significant differences were observed between the control group and experimental groups 1 and 2. According to the findings, $\mathrm{nZnO}$ can reduce the side effects of paclitaxel on liver tissue.

Keywords. histopathology, chemotherapy, transaminases, bilirubin, alkaline phosphatase

ديخر سرطانها نظير مثانه، يروستات، ملانوما، مرى و غيره است.

اين مولكول تجمع ميكروتوبولها از دايمرهاى توبولين را تسهيل

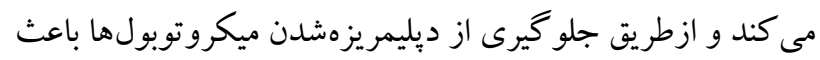

يايدارى آنها مىشود و بهاينترتيب از دوباره سازمان يافتن فعال و

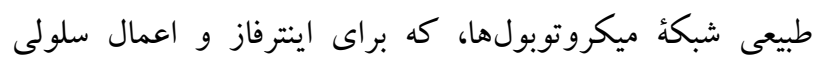

يا كلى تاكسل دارويى ضدسرطان است كه با متوقف كردن تقسيم سلولى از رشد سلولها جلو گيرى مى كند و ازاينطريق مرگك سلولهاى سرطانى را موجب مىشود. اين دارو نوعى عامل ضدميتوز است و كاربرد آن در سرطان يِيشرفتهُ تخمدان، سرطان يستان، شُش و سرطان نوع ساركوم كايوسى وابسته به AIDS و 
مقدار بالاى نانواكسيدروى در زمان يككهته (بالاى (ه) mo/kg)

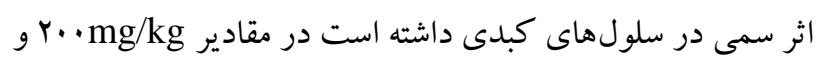

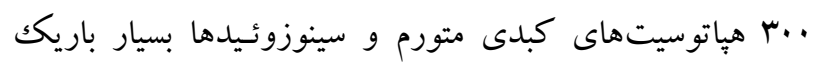

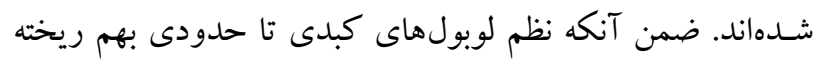

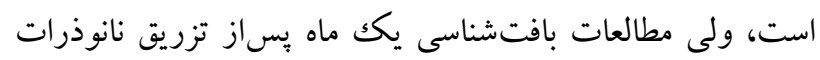

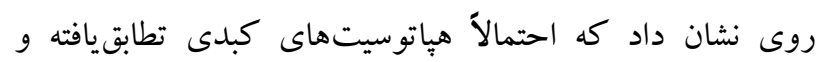

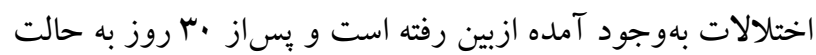

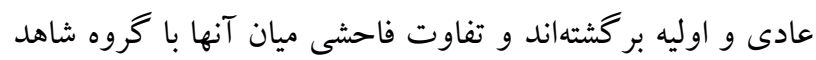
وجود نداشت (Prasad, 2008; Steel et al., 2009). در تحقيقات ديخر ثابت شده كه سلولهاى كويفر كبد نقش اصلى و

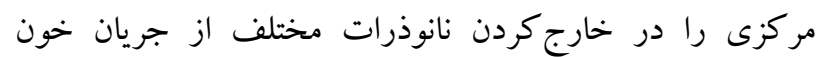

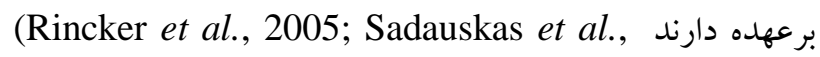
(2007. هدف تحقيق حاضر بررسى اثر محافظتى احتمالى نانوذرة اكسيد روى بر كبد موش هاى تيمارشده با باكلى تاكسل است.

\section{مواد و روشها}

باكلى تاكسل (ODS Pharma GmbH) از داروخانه هلال

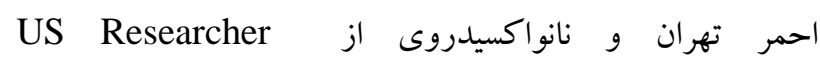
Nanomaterials

\section{روش تهيؤ محلول نانواكسيدروى}

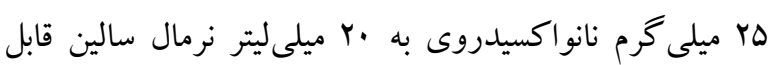

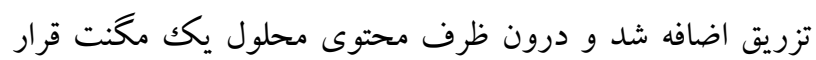
داده شد. سبس بشر محتوى محلول روى همزن مغناطيسى قرار

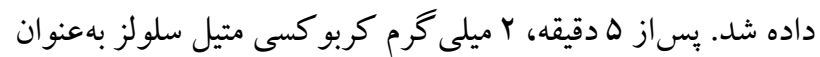
سورفكتانت به آن اضافه شد و مجدداً ه دقيقه ديخر روى همزن

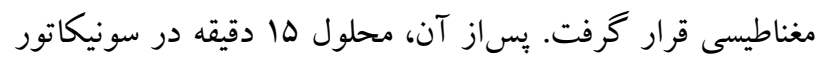

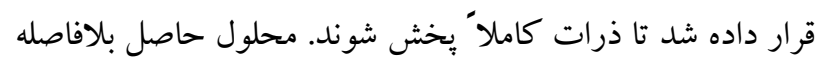

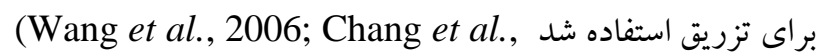
(2011. در اين تحقيق تجربى، از ها موش ماده بالغ نزاد ويستار

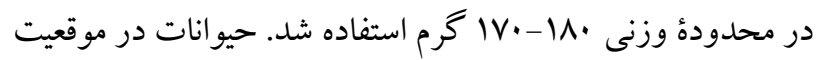

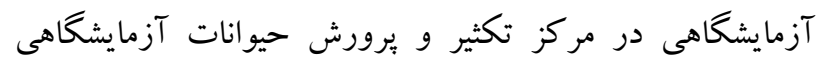
دانشگاه خوارزمى واقع در برديس تهران تحت وضعيت استاندارد،

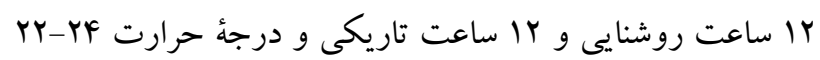

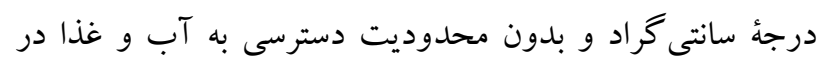

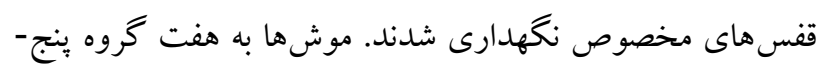

ميتوزى ضرورى است، جلو گيرى مىشود Masteropaolo et) al.,1995) نانو ذرات ويزگىهاى بسيار خاص فيزيكى و شيميايى ازنظر

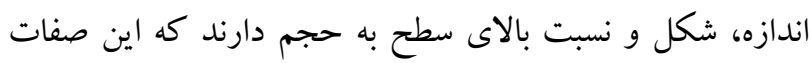

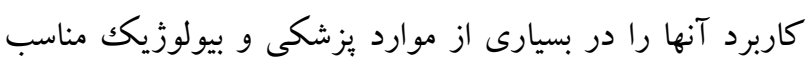

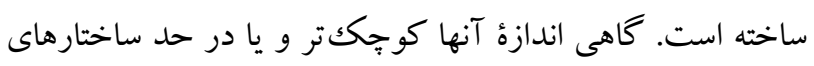

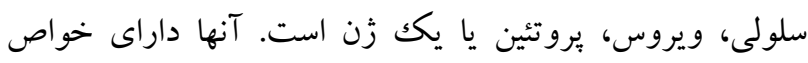

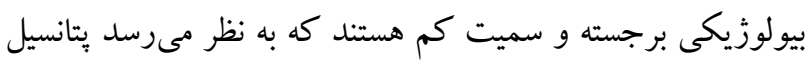
بالايى در عبور از سدهاى فيزيولوزيكك بدن به به بافتهاى هدف خاص را دارند (Jong et al., 2005). روى يكى از عناصر نادر است كه مقدار كم آن براى بدن

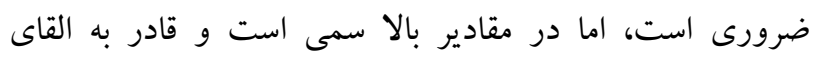
آيويتوز يا نكروز است (Ebisch et al., 2007). رايجترين تر كيب روى شكل اكسيد آن (ZnO) است كه استفاده از آن به -

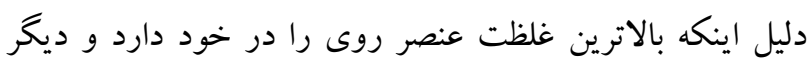
آنكه جذب آن در بدن زياد است و دستكاه گوارش آن بال را بهتر

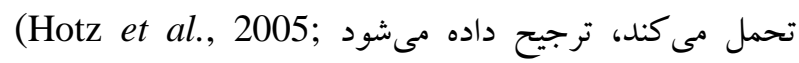
نانو اكسيد روى يكى از انواع جديد روى :Hollis et al., 2005) با خواص بيولوزيكى خاص و سميت كم است كه كارايى كافى

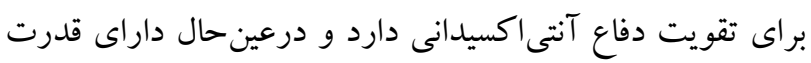

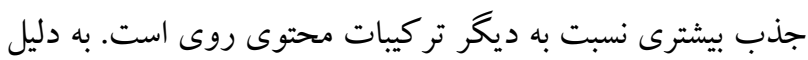

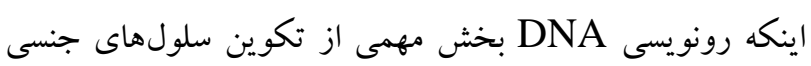

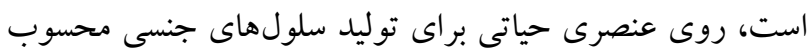

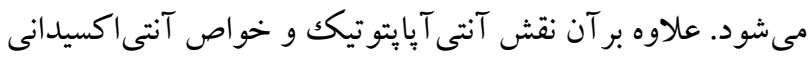

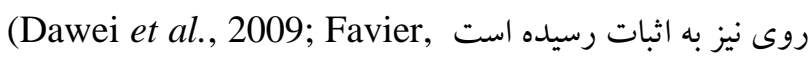

آزمايشها نشان دادهاند كه روى قادر است راديكالهاى آزاد

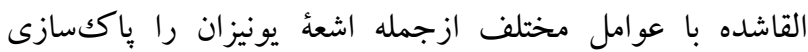
نموده، سبب كاهش ميزان MDA شود، بنابراين، آنتىاكسيدانى با لون توان حفاظتى بالا شناخته شده است. نانو اكسيد روى همجنين به

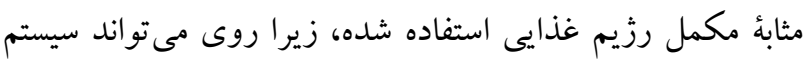
ايمنى را تحريك كند و در مسير ضدالتهابى عمل مى كند Dani) ن Dhawan, 2005)

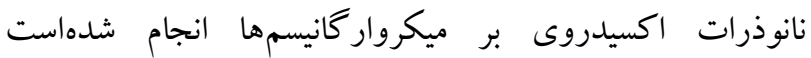

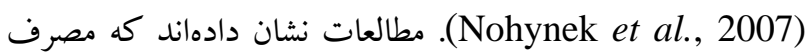


نتايج

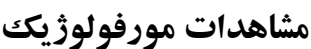

كبد موشهاى تحت القا با باكلى تاكسل ازنظر ظاهرى تفاوتهايى با كبد موشهاى سالم داشت. گروههاى تجربى كه فقط نانواكسيدروى را با مقادير هmg/kg و •إن دريافت كرده بودند

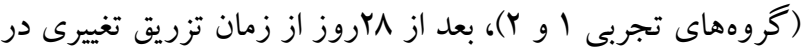
اندازه و شكل كبد آنها مشاهده نشد (در مقايسه با گروه كنترل).

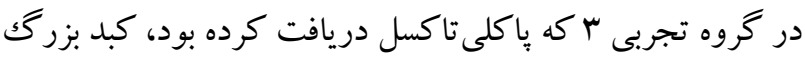

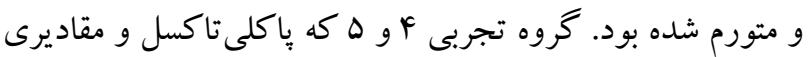

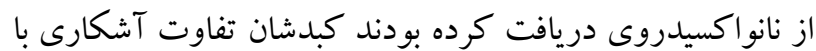

كروه كنترل نداشت (شكل ()). در بررسى كبد موشهاى گروه كنترل ساختار سلولى كبدى نرمالى مشاهده شد و هياتوسيتها از سياهر گك مركزى به ويرامون لبول تشعشع داشتند. گروههاى تجربى او ب (دريافت كننده مقادير

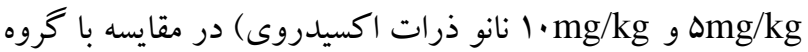
كنترل تصوير بافتى يكسانى از كبد داشتند و اندازهُ سلولها و عروق تفاوتى با گروه كنترل نشان نداد.

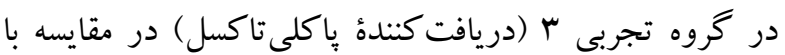

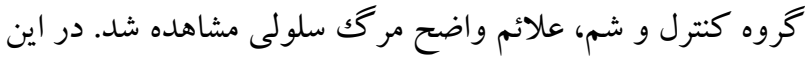

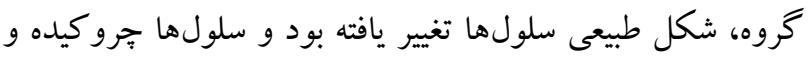
هسته آنها بسيار متراكم شده بود. بهعلاوه، بين سلولها فاصله ايجاد

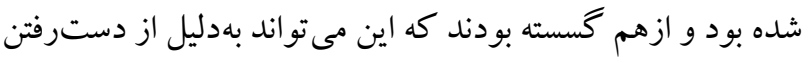
تماس سلول به سلول درنتيجه وقوع مرگك سلولى باشد. ضمناً

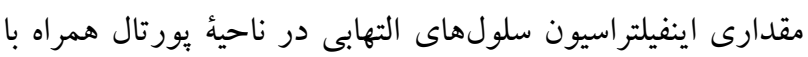
تكثير براكندة سلولهاى كويفر در بين سلولهاى كبدى مشاهده

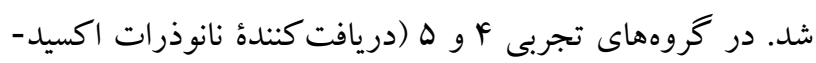

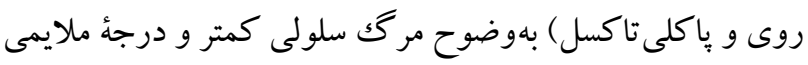

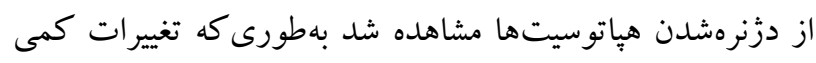
در شكل سلولها و هستة آنها وجود داشت (شكل هاى ها-Y). بر رسىهاى آنزيمى ميزان ALP در گروه تجربى لَ در مقايسه با گروه كنترل و شم

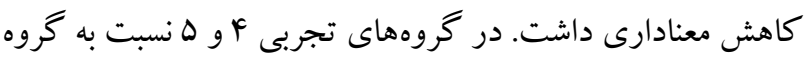

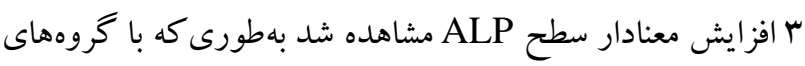

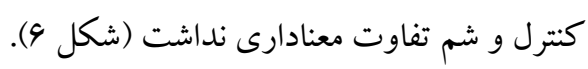

تايى تقسيم شدند: گروه كنترل كه با شرايط وزنى و غذايى مشابه با ديخر گروهها و بدون هر گونه تيمارى بودند؛ گروه شم كه سالين

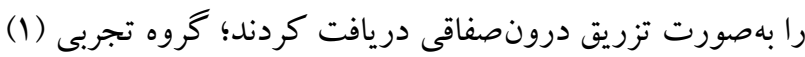

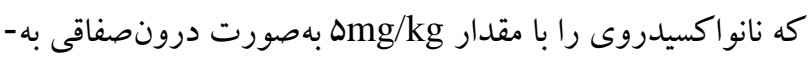
مدت r روز دريافت كردند. گروه تجربى (Y) نانواكسيد روى را با مقدار mg/kg · ابهورت درونصفاقى بهمدت بم روز دريافت

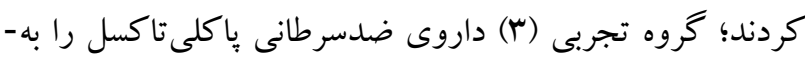
مدت بروز بهصورت درونصفاقى با مقدار

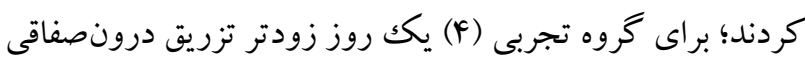

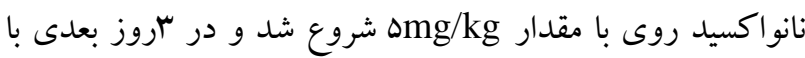

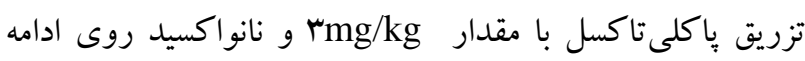

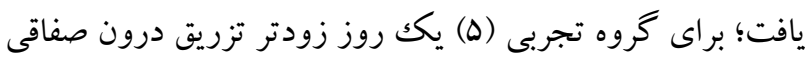

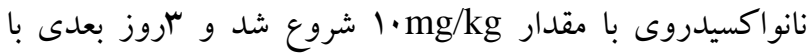
تزريق پياكلىتاكسل با مقدار rmg/kg و نانواكسيدروى ادامه

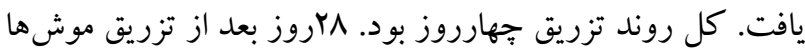

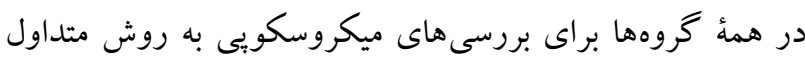

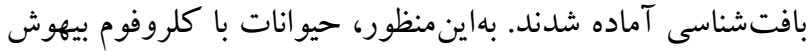

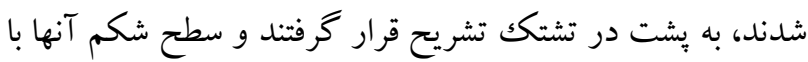
الكل •لادرصد استريل شد. شكم با يك قيجى جراحى باز شد و

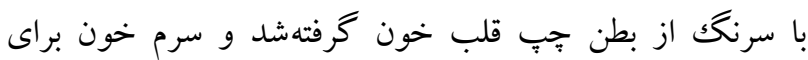
بررسى آنزيمهاى كبدى آمادهش. از دستكاه فتومتر بيوشيمى Mindray BS400 و كيت آزمون آنزيمى Bioo در

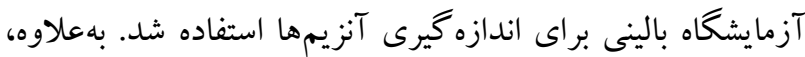

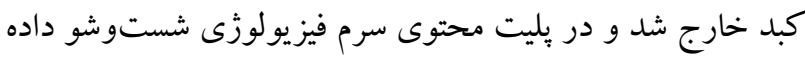

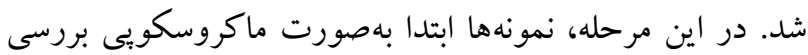
شدند. سبس نمونها بهمدت \1 ساعت در فيكساتور بوئن قرار

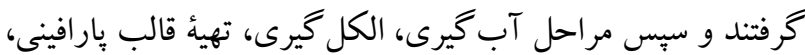

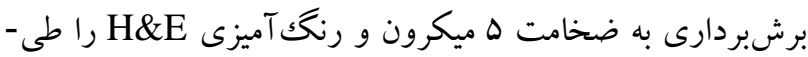
كردند تا براى بررسى هاى ميكروسكويى آماده شدند.

تحليل آمارى

دادههاى بهدست آمده از تحليل آنزيمهاى كبدى با استفاده از نرمافزار SPSS و آزمون آمارى ANOVA-يككرفه تحت بررسى قرار گرفت. سطح معنى دارى 0.05>p در نظر گرفته شدو و

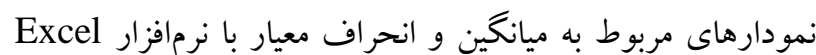

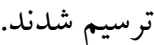



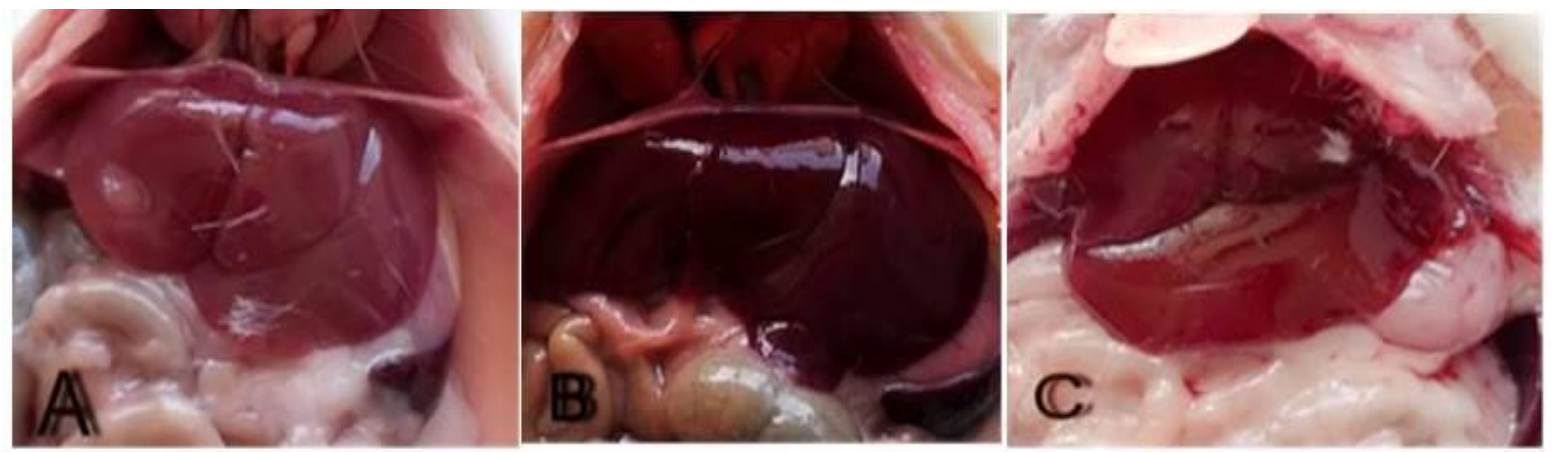

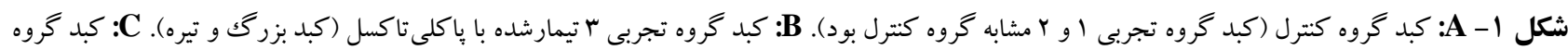

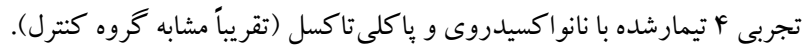

Fig. 1. A: Liver in control group (livers in experimental groups 1 and 2 were the same). B: Liver of experimental group 3, treated with paclitaxel (large and dark). C: Liver of experimental group 4, treated with paclitaxel and nano zinc oxide (more or less similar to the control group).

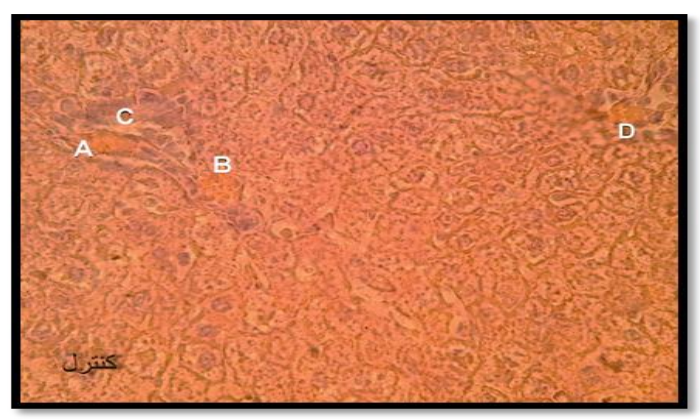

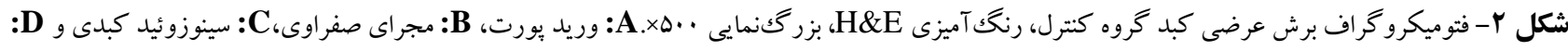

$$
\begin{aligned}
& \text { سرخر ك كبدى. }
\end{aligned}
$$

Fig. 2. Photomicrograph of liver cross section in control group. H\&E staining, mag. 500×. A: portal vein, B: bile duct, C: li-ver sinusoid, D: liver artery.

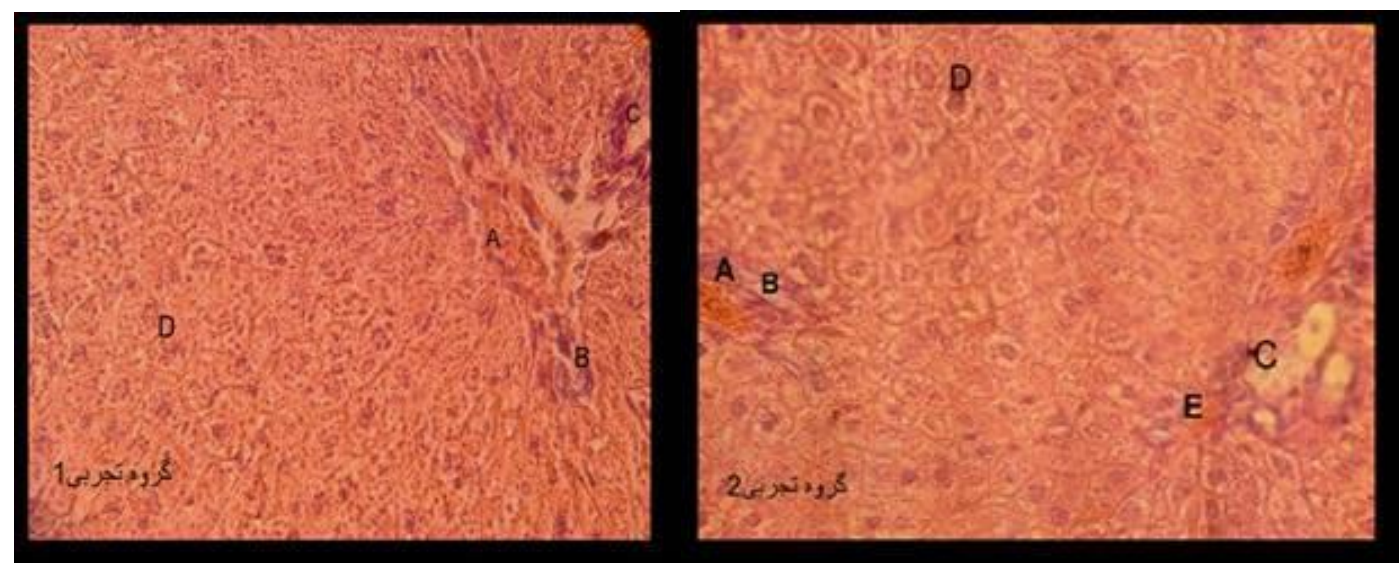

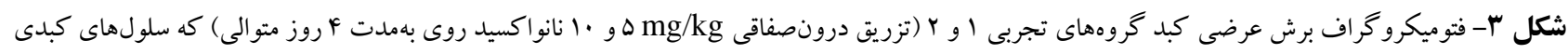

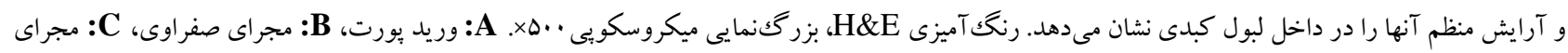

$$
\text { كبدى، D: سلول كبدى، E: }
$$

Fig. 3. Photomicrographs of liver cross sections in experimental groups 1 and 2 (intra-peritoneal injections of 5 and 10 $\mathrm{mg} / \mathrm{kg}$ nano zinc oxide for 4 subsequent days) showing hepatocytes and their regular arrangements within liver lobules. H\&E stai-ning, mag. 500×. A: portal vein, B: bile duct, C: liver duct, D: hepatocyte, E: a branch of liver artery. 


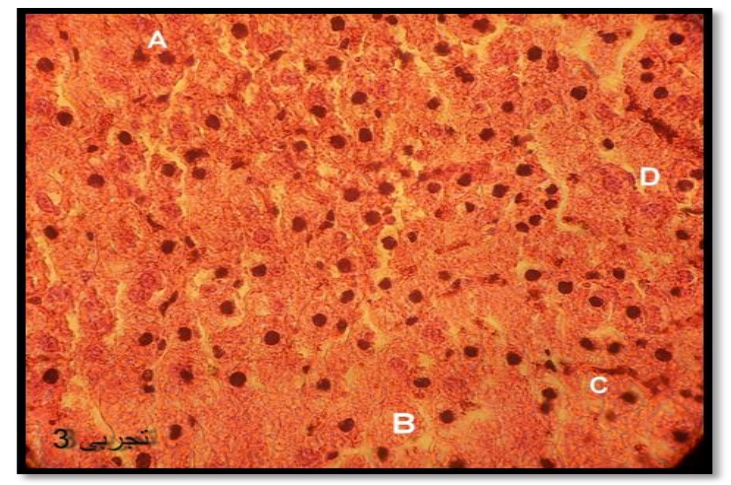

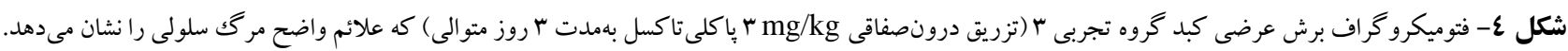

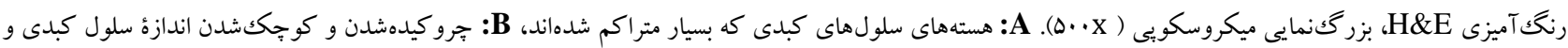

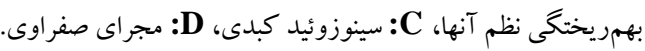

Fig. 4. Photomicrograph of liver cross section in experimental group 3 (intra-peritoneal injection of $3 \mathrm{mg} / \mathrm{kg}$ paclitaxel for 3 subsequent days) shows obvious signs of cell death. H\&E staining, mag.500×. A: very condensed liver cells nuclei, B: shrinkage and reduction of liver cell size and their disarrangements, C: liver sinusoid, D: bile duct.
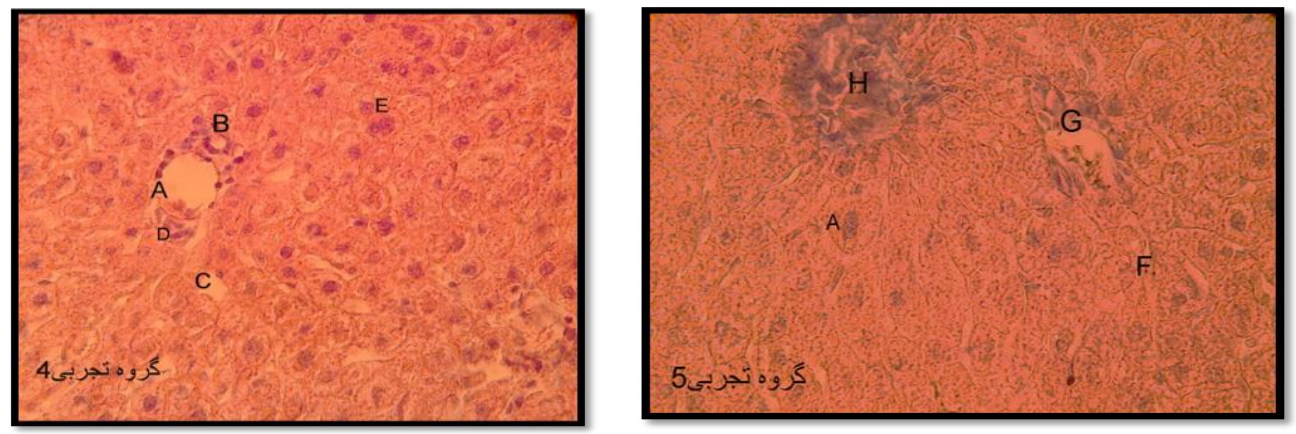

شكل 0- فتوميكرو گراف برش عرضى كبد گروهاى تجربى \& و ها (تزريق درون صفاقى با كلى تاكسل و نانواكسيدروى) كه در مقايسه با كروه بِاكلىتاكسل تغييرات

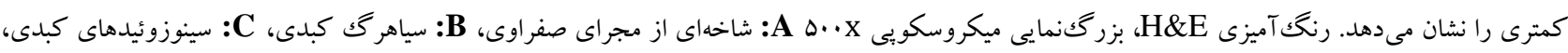

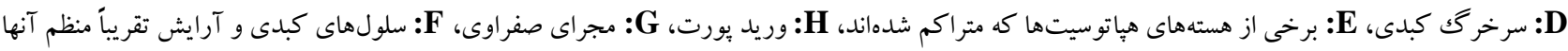

در داخل لبول كبدى.

Fig. 5. Photomicrographs of liver cross sections in experimental groups 4 and 5 (intra-peritoneal injection of paclitaxel and nano zinc oxide) showing less alterations compared to paclitaxel group. H\&E staining, mag. 500×. A: a branch of bile duct, B: liver vein, C: liver sinusoids, D: liver artery, E: some hepatocyte nuclei are condensed, H: portal vein, G: bile duct, F: hepatocytes and their approximate regular arrangements within liver lobules.

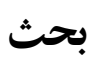

كبد بزرگكترين اندام در بدن مهرهداران و جايگاه اصلى

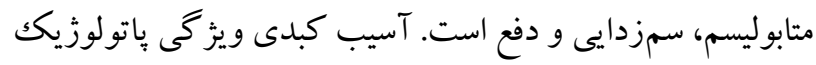
مشترك بسيارى از بيمارىهاى كبدى است. بيمارىهايى نظير فيبروز كبدى، سيروز و حتى سرطان كبد مىتواند از آسيب طولانى مدت به كبد ناشى شود (Yuan et al., 2010). بنابراين، ييش گيرى از آسيب كبدى و درمان آن ازنظر بالينى كليد درمان بيمارىهاى كبدى محسوب مى شود.
ميز ان آسپارتات آمينو ترانسفراز (AST)، آلانين ترانسفرا (ALT) و نيز بيلىروبين در گروه تجربى ب كه ياكلى تاكسل دريافت كرده بودند بهطور معنادارى نسبت به گروههاى كنترل و شم افزايش يافت ولى در كروههاى تجربى ا و r تفاوت معنادارى با گروه

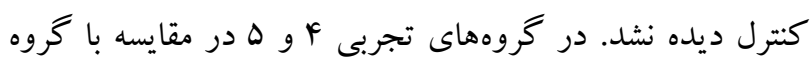
تجربى ب كاهش معنادارى مشاهده شد؛ بهطورى كه با گرووهاى كنترل و شم تفاوت معنادارى نداشت (شكل هاى V-9 ). 


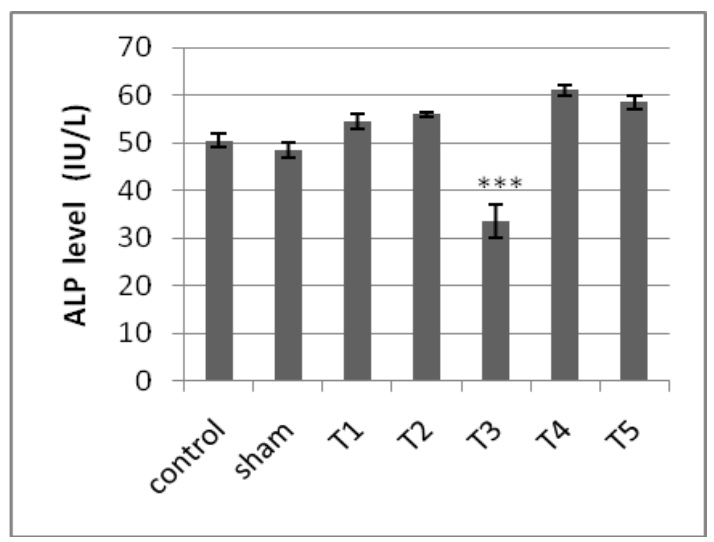

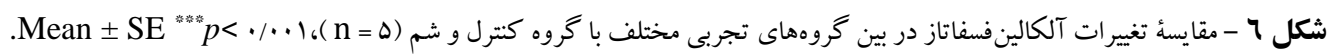

Fig. 6. Alkaline phosphatase alterations among different experimental groups compared with the control and sham groups. $(\mathrm{n}=5), \stackrel{* * *}{p} p<0.001$. Mean \pm SE.

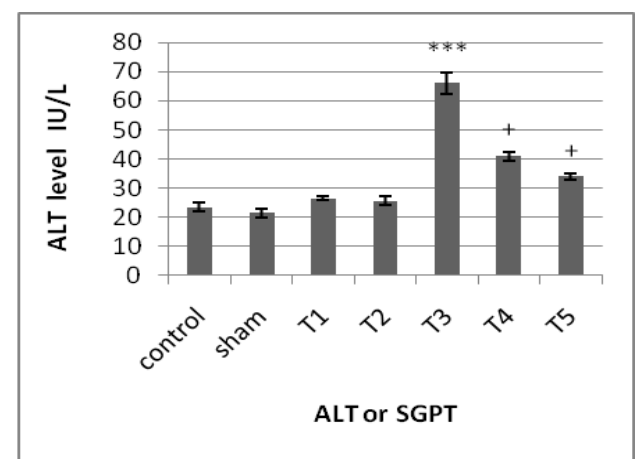

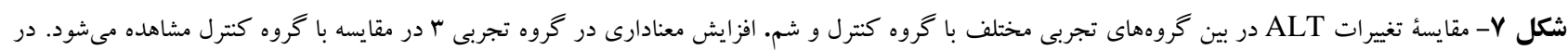

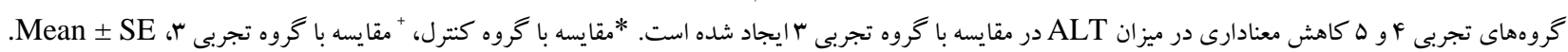

Fig. 7. ALT alterations among different experimental groups compared with the control and sham groups. A significant increase in experimental group 3 compared with the control group was observed. In experimental groups 4 and 5, significant reductions compared with the experimental group 3 were observed. " compared with the control group, ${ }^{+}$compared with the experimental group 3, Mean \pm SE.

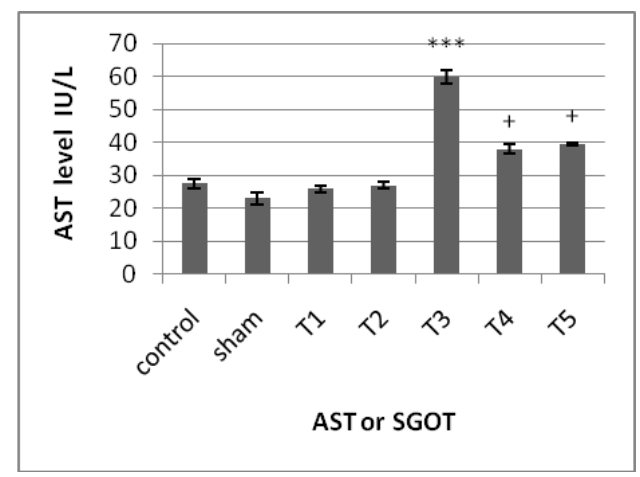

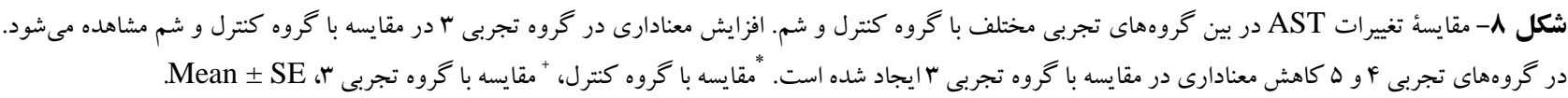

Fig. 8. AST alterations among different experimental groups compared with the control and sham groups. A significant increase in experimental group 3 compared with the control group was observed. In experimental groups 4 and 5, significant reductions compared with the experimental group 3 were observed. ${ }^{*}$ compared with the control group, ${ }^{+}$compared with the experimental group 3, Mean \pm SE. 


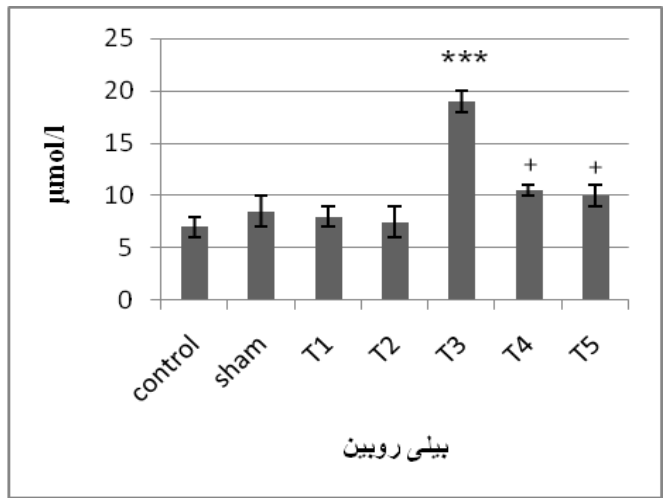

شكل q- مقايسٔ تغييرات بيلى روبين در بين گروههاى تجربى مختلف با گروه كنترل و شم. افزايش معنادارى در گروه تجربى ك در مقايسه با گروه كنترل مشاهده

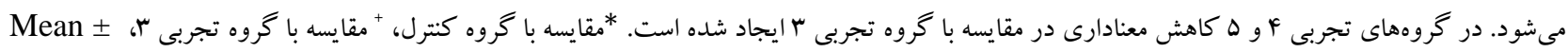

Fig. 9. Bilirubin alterations among different experimental groups compared with the control and sham groups. A significant increase in experimental group 3 compared with the control group was observed. In experimental groups 4 and 5 , significant reductions compared with the experimental group 3 were observed. " compared with the control group, ${ }^{+}$compared with the experimental group 3, Mean \pm SE.

تاكسل شد (شكل IC) كه مؤيد نقش حفاظتى نانواكسيد روى بر

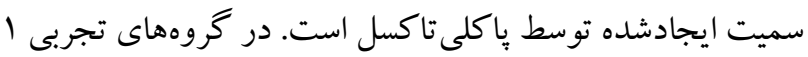

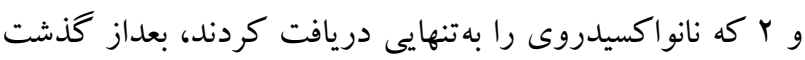

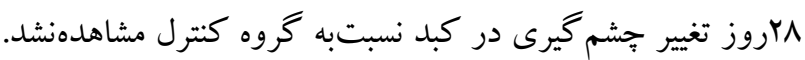
كبد با استفاده از توانايى سم زدايى قادر است ذرات نانواكسيد

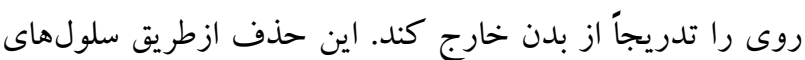

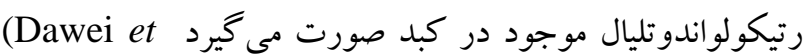
al., 2009 و سلولهاى كويفر نقش اصلى را در خارجكردن (Sadauskas et al., نانوذرات از جريان خون برعهده دارند

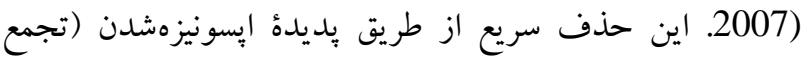
يروتئينهاى خون در اطراف نانوذرات) رخ مىدهد كه باعث

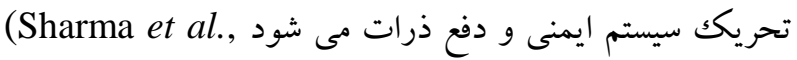
(2009. آزمونهاى عمل كرد كبد بهطور بالينى براى غربال گرىى

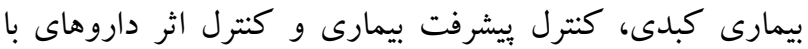
خاصيت سميت كبدى استفاده مىشوند. متداولترين آزمونهاى عملكردى كبد شامل سرم آمينو ترانسفرازها، آلكالينفسفاتاز، بيلى روبين و آلبومين است (Abolfathi et al., 2011). فعاليتهاى آنزيمهاى AST، و ALP و ALP حساسترين بيوماركرهايى هستند كه مستقيماً در ميزان آسيب و سميت كبدى نقش دارند. افزايش در سطوح سرمى آنزيمهاى AST و ALT معرف اينفيلتر -

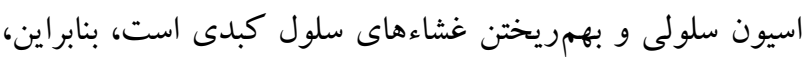

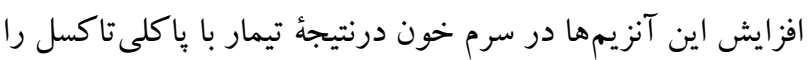

باكلى تاكسل دارويى ضدسرطان است كه با جلو گيرى از ديليمريزهشدن ميكروتوبولها موجب بايدارى آنها مىشود و از سازمانيابى مجدد طبيعى و فعال آنها كه براى اينترفاز و اعمال

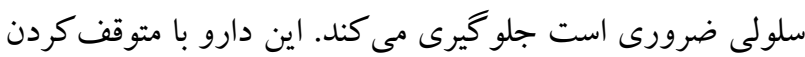

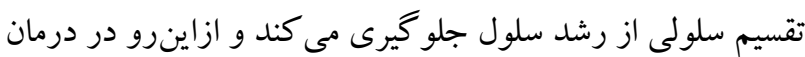
(Mastropaolo et al., بسيارى از سرطانها استفاده مىشود (1995. تغيير شكل زيستى اين دارو در كبد كه جايگاه اصلى دفع آنس

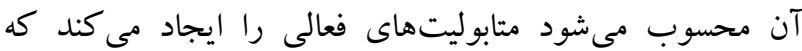
سميت كبدى را موجب مى شوند. در مطالعٔ حاضر يكك مدل آسيب كبدى در موش بهوسيلة تزريق درونصفاقى mg/kg پ ياكلى تاكسل بهمدت ساروز ايجاد شد و اثر دو مقدار mg/kg ه و •ا نانواكسيدروى بر آسيبهاى ايجاد شده بلوسيلة پاكلىتاكسل در كبد تحتبررسى قرار گرفت. در مطالعات سمشناسى وزن اندام معيار مهمى براى سنجش سميت اندام است. در مطالعة حاضر، كاربرد داروى ضدسرطان پِاكلى تاكسل به افزايش درخور ملاحظه در اندازه كبد موشها منجر شد؛ بهطورى كه كبد متورم، بزرگك و بسيار تيره شده بود (شكل B (I). افزايش وزن كبد درنتيجهُ اثر تو كسيكولوزيكى مواد مختلف را (Sharma et al., 2005; محققان ديخر نيز كزارش كردهاند Heikal et al., 2012b; Heikal \& Soliman, 2010; Saafi (بهرحال، كاربرد توأم نانواكسيد روى موجب al al., 2011) كاهش درخور توجه اندازه كبد در موشهاى تيمارشده با باكلى - 
(Goel et al., كند و اغتشاش در نفوذيذيرى را بهبود مىبخشد

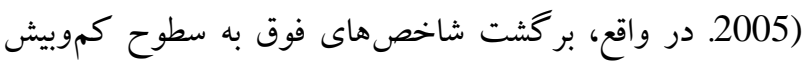
نرمال سرمى مبين بهبود مكانيسم عملكردى و ترشحى سلولهاى بهاى كبدى است. استفاده از نانواكسيدروى به تنهايى تغيير معنادارى را در سطوح آنزيمهاى AST، ALT و ALP سرم و نيز در ميزان بيلىروبين خون نسبت به كنترل ايجاد نكرد كه نشاندهندة فقدان سميت دوزهاى نانو اكسيد روى به كاررفته است. تغييرات هيستويا-

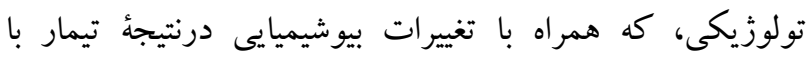

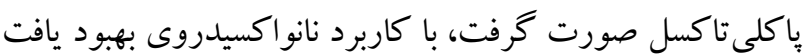
كه مىتوان آن را به ظرفيت آنتىاكسيدانى و ضدالتهابى نانو اكسيدروى نسبت داد.

\section{نتيجه كيرى}

نتايج مطالعه حاضر نشانداد كه ياكلى تاكسل موجب آسيب و

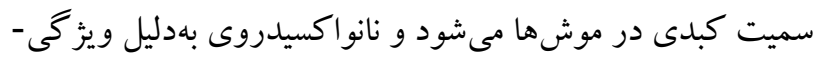
هاى آنتىاكسيدانى و ضدالتهابى خوداسترساكسيداتيو را كاهش مىدهد و تماميت ساختمانى غشاى سلولى را بهبود مىبخشد و نهايتاً تغييرات هيستوياتولوزيكى و نيز به همريختخكى هاى بيوشيميا-

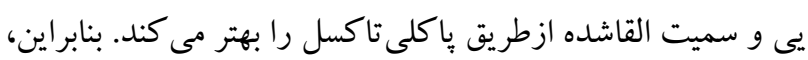

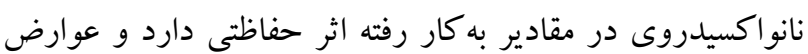
جانبى بِاكلى تاكسل را كاهش مىدهد. بههرحال، پٍتانسيل حفاظت

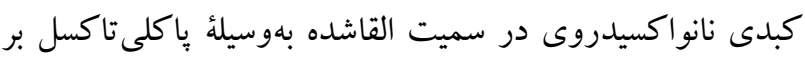
كبد به مطالعات بيشترى نياز دارد.

سياسگز ارى اين تحقيق در قالب بروزةٌ تحقيقاتى در آزمايشگاه سلولى -

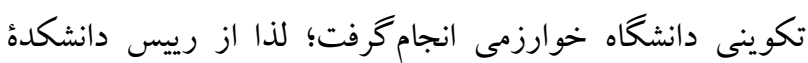

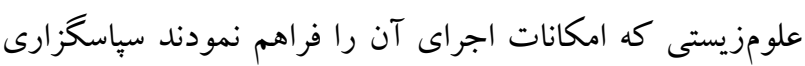
مى شود.

\section{REFERENCES}

Abolfathi, A.B., Mohajeri, D., Rezaie, A. and Nazeri, M. 2011. Protective effects of green tea extract against hepatic tissue injury in Streptozotocin- induced diabetic rats. - Evi. Based Compl. Alter. Med. 2012:1-10.

Chang, H., Choi, S., Kos, W. and Chun, H.S. 2011. Effect of particle size of zinc oxides on cytotoxicity and cell permeability in caco-2 cells. - J. Food Sci. Nutr. 10: 174178.
مى توان به آزادسازى آنها از سيتويلاسم بهدرون گردش خون نسبت داد Drotman \& Lawhorn, 1978; Dasguptal et يكك آنزيم متصل به غشاء است و تغيير آن ALP al.,1996)

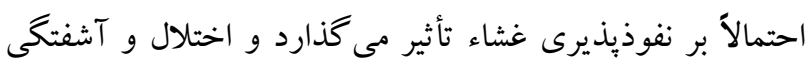
در انتقال متابوليتها ايجاد مى كند (Mehana et al., 2012). ازطرف ديخر، بيلىروبين و آلبومين با عملكرد سلول كبدى إنى

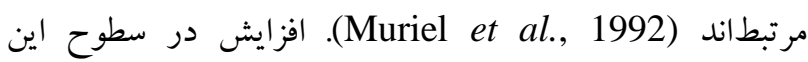
يروتئين ها مبين نكروز و واكنشهاى التهابى است Navarro et) (al., 1993; Kuzu et al., 2007) شيميايى باعث ايجاد آسيب اكسيداتيو ازطريق توليد گونههاى

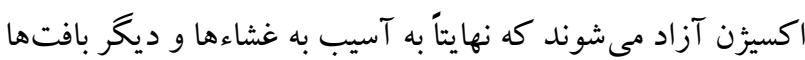
منجر مىشوند (Vuillaume, 1987). يراكسيداسيون ليييد و آسيب هاى اكسيداتيو يروتئين كه بهوسيلة راديكالهاى آزاد ايجاد مىشوند نقش مهمى در وقايع باتولوزيكى شديد ايفا مى كندا .(Stohs \& Bagchi, 1995; Stadtman \& Levin, 2000) آسيب اكسيداتيو به كبد بهوسيلة مواد شيميايى و داروهاى مختلف با افزايش سطح MDA سرم و محتواى بروتئين كربونيل و كاهش به

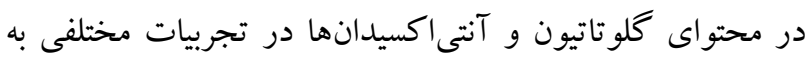

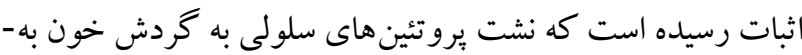

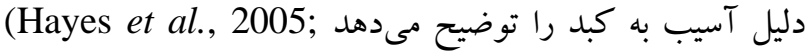
Verma et al., 2007; Mansour \& Mossa, 2010; Heikal \& Soliman, 2010; Heikal et al., 2011, $.2012 b)$

يتانسيل حفاظت كبدى نانواكسيد روى در سميت القاشده بهوسيلة باكلى تاكسل بر كبد به مطالعات گستردهاى نياز دارد. نتايج مطالعه حاضر آشكار كرد كه استفاده از نانواكسيد روى در موشهاى تيمارشده با پِاكلىتاكسل موجب كاهش معند معنادار سطوح AST و افزايش معنادار سطح ALP سرم شد؛ بهطورىكه تفاوت معنادارى با گروه كنترل مشاهده نشد. سطح بيلىروبين خون نيز كه در تيمار با باكلى تاكسل افزايش معنادارى يافته بود در

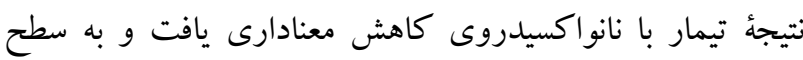
كنترل نزديكك شد؛ بهطورى كه تفاوت معنادارى با كنترل نشان

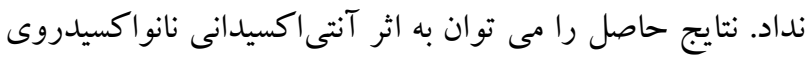
نسبت داد (Dawei et al., 2009; Favier, 1992) كه با لإسل كاهش راديكالهاى آزاد، يُراكسيداسيون ليييد و آسيبهاى

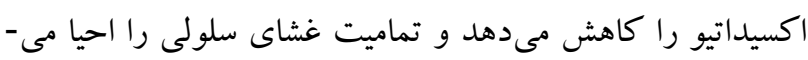


Dani, V. and Dhawan, D.K. 2005. Radioprotective role of zinc following single dose radioiodine (1311) exposure to red blood cells of rats. - Indian J. Med. Res. 122: 338342 .

Dasgupta, S., Ghosh, S. and Das, K.K. 1996. Transaminase activities in some metabolically active tissues in nickel treated rats under protein restriction. - Indian J. Physiol. Allied Sci. 50: 27-33.

Dawei, A., Zhisheng, W. and Anguo, Z. 2009. Protective effects of nano $\mathrm{ZnO}$ on the primary culture mice intestinal epithelial cells in in vitro against oxidative injury. Int. J. Nanotech. Appl. 3: 1-6.

Drotman, R. and Lawhorn, G. 1978. Serum enzymes as indicators of chemically induced liver damage. - Drug Chem. Toxicol. 1: 163-171.

Ebisch, L., Thomas, C., Peters, W., Braat, D. and SteegersTheunissen, R. 2007. The importance of folate, zinc and antioxidants in the pathogenesis and prevention of subfertility. - Hum. Reprod. 13: 163-174.

Favier, A.E. 1992. The role of zinc in reproduction hormonal mechanisms. - Biol. Trace. Elem. Res. 32: 363-382.

Goel, A., Dani V. and Dhawan, D.K. 2005. Protective effects of zinc on lipid peroxidation, antioxidant enzymes and hepatic histoarchitecture in chlorpyrifos-induced toxicity. - Chemo-Bio. Inter. 156: 131-140.

Hayes, J.D., Flanagan, J.U. and Jowsey, I.R. 2005. Glutathione transferases. Annu. Rev. Pharmacol. Toxicol. 45: 51-88.

Heikal, T.M., El-Sherbiny, M., Hassan, S.A., Arafa, A. and Ghanem, H.Z. 2012b. Antioxidant effect of selenium on hepatotoxicity induced by chlorpyrifos in male rats. - Int. J. Pharm. Sci. 4: 603-609.

Heikal, T.M., Ghanem, H.Z. and Soliman, M.S., 2011. Protective effect of green tea extracts against Dimethoate induced DNA damage and oxidant/antioxidant status in male rats. - Biol. Health Sci. Bulletin 3: 1-11.

Heikal, T.M. and Soliman, M.S. 2010. Effect of fish oil supplementation on brain DNA damage and hepatic oxidant/antioxidant status in Dimethoate- treated rats. - J. Egy. Soci. Toxicol. 42: 1-9.

Hollis, G.R, Carter, S.D, Cline, T., Crenshaw, T.D., Cromwell, G.L. and Hill, G. 2005. Effects of replacing pharmacological levels of dietary zinc oxide with lower dietary levels of various organic zinc sources for weanling pigs. - J. Anim. Sci. 83:2123-2129.

Hotz, C., DeHaene, J., Woodhouse, L.R., Villalpando, S., Rivera, J.A. and King, J.C. 2005. Zinc absorption from zinc oxide, zinc sulfate, zinc oxide + EDTA, or sodiumzinc EDTA does not differ when added as fortifications to maize tortillas. - J. Nutr. 135:1102-1105.

Jong, W.H., Roszek, B. and Geertsma, R.E. 2005. Nanotechnology in medical applications: possible risk for human health. - The Dutch National Institute for Public Health and the Environment (RIVM) Report 265001002.

Kuzu, N., Metin, K., FerdaDagli, A., Akdemir, F. Orhan, C., Yalniz, M., Ozercan, I.H., Sahin, K., Bahcecioglu, I.H. 2007. Protective role of genistein in acute liver damage induced by carbon tetrachloride. - Medi. Inflamm. 2007: 36381-31387.

Mansour, S.A. and Mossa, A.H. 2010. Oxidative damage, biochemical and histopathological alterations in rats ex- posed to chlorpyrifos and the antioxidant role of zinc. Pest. Biochem. Physiol. 96: 14-23.

Mastropaolo, D., Camermanm, A., Luo, U.D., Brayer, G. and Camerman, N. 1995. Crystal and molecular structure of paclitaxel (Taxol). - Proc. Natl. Acad. Sci. USA 92: 6920-6924.

Mehana, E.E., Meki, A.R., and Fazili, K.M. 2012. Ameliorated effects of green tea extract on lead induced liver toxicity in rats. - Exp. Toxicol. Pathol. 64: 291-295.

Muriel, P., Garciapina, T., Perez-Alvarez, V., and Mourelle, M. 1992. Silymarin protects against Paracetamol-induced lipid peroxidation and liver damage. - J. Appl. Toxicol. 12: 439-442.

Navarro, C., Montilla, P., Martin, A., Jimenez, J. and Utrilla, P. 1993. Free radical scavenger and antihepatotoxic activity of Rosmarinus tomentosus. - Plant. Med. 59: 312-314

Nohynek, G.J., Lademann, J., Ribaud, C. and Roberts, M.S. 2007. Grey goo on the skin nanotechnology, cosmetic and sunscreen safety. - Crit. Rev. Toxicol. 37: 251277.

Prasad, A.S. 2008. Clinical immunological, anti-inflammatory and antioxidant roles of zinc. - Exp. Geront. 43: 370-377.

Rincker, M.J., Hill, G.M., Link, J.E., Meyer, A.M. and Rowntree, J.E. 2005. Effects of dietary zinc and iron supplementation on mineral excretion, body composition and mineral status of nursery pigs. - J. Anim. Sci. 83: 27622774

Saafi, E.B., Louedi, M., Elfeki, A., Zakhama, A., Najjar, M.F., Hammamia, M., and Achour L. 2011. Protective effect of date palm fruit extracts (Phoenix dactylifera L.) on dimethoate induced-oxidative stress in rat liver. Exp. Toxicol. Pathol. 63: 433-441.

Sadauskas, E., Wallin, H., Stoltenberg, M., Vogel, U., Deoring, P., Larsen, A. and Danscher, G. 2007. Kupffer cells are central in the removal of nanoparticles from the organism. - Parti. Fiber Toxicol. 4:10-17.

Sharma, Y., Bashir, S., Irshad, M., Nag, T.C. and Dogra, T.D. 2005. Dimethoate induced effects on antioxidant status of liver and brain of rats following subchronic exposure. - Toxicol. 215: 173-181.

Sharma, V., Shukla, R.K., Satena, N., Pemer, D. and Das M, Dhawan, A. 2009. DNA Damaging potential of zinc oxide nanoparticles in human epidermal cells. - J. Toxicol. Lett. 185: 211-218.

Stadtman, E.R. and Levine, R.L. 2000. Protein oxidation. Annal. NY. Acad. Sci. 899: 191-208.

Steel, A., Bayer, I. and Loth, E. 2009. Inherently super oleophobic nanocomposite coatings by spray atomization. - Nano Lett. 9: 501-505.

Stohs, S.J and Bagchi, D. 1995. Oxidative mechanisms in the toxicity of metal ions. - Free Radical Bio. Med. 18: 321-336.

Verma, R.S., Mehta, A. and Srivastava, N. 2007. In vivo chlorpyrifos oxidative stress: attenuation by antioxidant vitamins. - Pestic. Biochem. Phys. 88: 191-196.

Vuillaume, M. 1987. Reduced oxygen species, mutation, induction, and cancer initiation. - Mutat. Res. 186: 4372. 
Wang, B., Feng, Y., Wang, T.C. and Jia, G. 2006. Acute toxicity of nano and microscale zinc powder in health of adult mice. - Toxic. Lett. 116: 115-123.

Yuan, H.D., Jin, G.Z. and Piao, G.C. 2010. Hepatoprotective effects of an active part from Artemsio sacrorum Ledeb against acetaminophen-induced toxicity in mice. J. Ethnopharmacol. 127: 528-533.

\section{How to cite this article:}

Mohseni Kouchesfahani, H. and Ostadbagher Kashi, A. 2016. The protective effect of $\mathrm{ZnO}$ nanoparticles on liver and impairments induced by paclitaxel treatment in female Wistar rat. - Nova Biol. Rep. 3: 218-227.

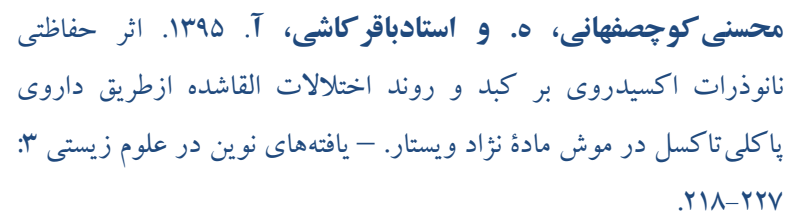

